\title{
Investigation of Mechanical Properties of Friction Stir Spot Welded Light Metal Alloys
}

\author{
Ahmet Atak and Aydın Şik \\ Dep. of Industrial Design, Science and Technology Institute, Gazi University, Eti Mah. Yükseliş Sok. 5, 06570 Maltepe, Ankara, Turkey
}

\begin{abstract}
The use of light metals today is of great importance, for example in the automotive, aviation and aerospace industries, where energy consumption is minimized and thus the economy is being attempted. By using light metals, weight is reduced so that energy is saved. Aluminum and magnesium alloys are particularly used thanks to their lightweight. Vehicles in the automotive, aerospace and space industries are expected not only to have lightweight but also high static and dynamic strengths since they are exposed to static and dynamic cyclic loads. However, the structural components can quickly become fatigued and fail under cyclic load due to the notch factor of the joining zones. Compared to the fusion welding method, joining of material is realized mechanically below the melting point of the material in the friction stir spot welding (FSSW) method. Thus, the fatigue strength of the assembly is much higher than that of the fusion welding. In this study, light metal alloy of magnesium AZ31B and aluminum EN AW 2024 were joined with FSSW method and mechanical properties of this joins were also carried out.
\end{abstract}

Key words: Friction stir spot welding, joining of magnesium, joining of aluminum, welding of light metals.

\section{Introduction}

In consequence of the limited energy resources in the world and the increasing awareness of energy saving in human beings, manufacturers in the automotive and aerospace industries are using lightweight metals to save fuel and thus saving energy in vehicles they produce [1-5].

There are various technical problems in the resistance spot welding, which is one of the joining methods in fusion welding of light metals. The most important of these is the realization of the joining above melting point, which burns and causes brittleness of the material, the joining defects and the notch factor; causing fatigue damage to vehicles or machines exposed to cyclical dynamic loads [6-11].

In this study, aluminum alloys (EN AW 2024) and magnesium alloy (AZ31B) sheets were lab-joined by using FSSW method, and mechanical tests results are given.

Corresponding author: Ahmet Atak, M.Sc., doctorate student, research fields: structural design \& analysis, light weight structure, joining of light metals, friction stir spot welding and fatigue design $\&$ analysis.

\section{Experimental}

In order to verify the selected material, standard material tests were carried out. Tension-shear test and three points banding tests were also carried after joining the materials.

\subsection{Base Material Tension Tests}

Mechanical properties of base material were verified by using INSTRON 3369 tension test machine according to ISO 6892-1. The dimensions and picture of tension test samples are given in Figs. 1 and 2.

Tables 1 and 2 show the chemical composition and mechanical properties of magnesium alloy sheet AZ31B according to the standards [12].

Fig. 3 shows the tensile test sample of aluminum alloy EN AW 2024-T4 according to ISO 6892-1.

Tables 3 and 4 show the chemical composition and mechanical properties of aluminum alloy sheet EN AW 2024-T4 according to the standards [13].

Since the materials which are having $E$ modulus lower than $150,000 \mathrm{MPa}$ are investigated, tension test speeds were selected according to Table 3 in ISO $6892-1$ which is $1 \mathrm{~mm} / \mathrm{min}$ respectively $18 \mathrm{MPa} / \mathrm{s}$. 


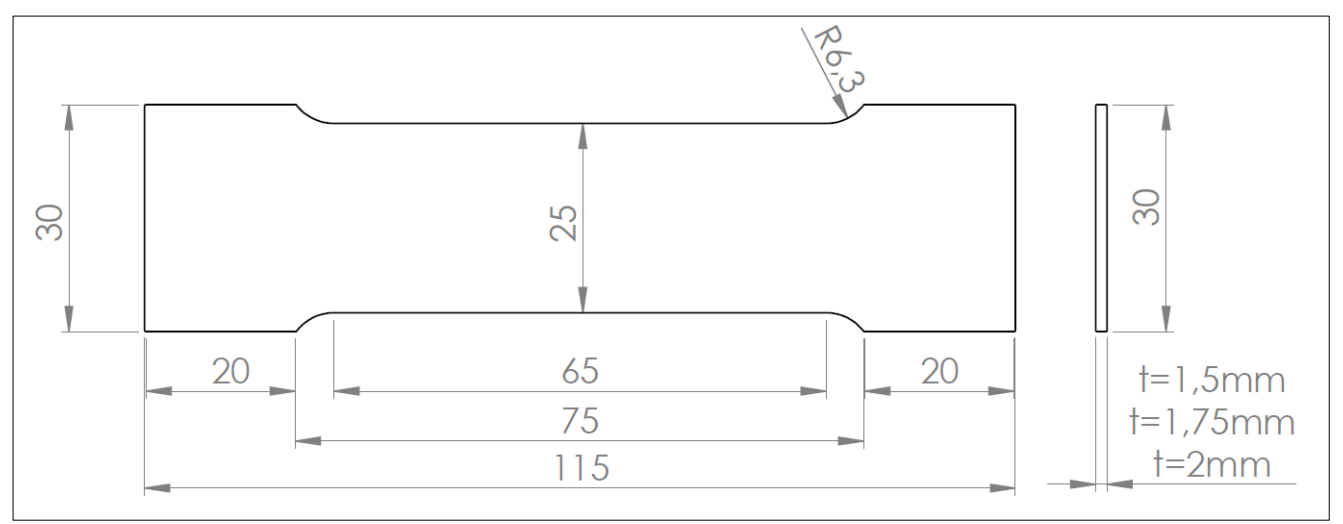

Fig. 1 Tension test sample dimension according to ISO 6892-1.

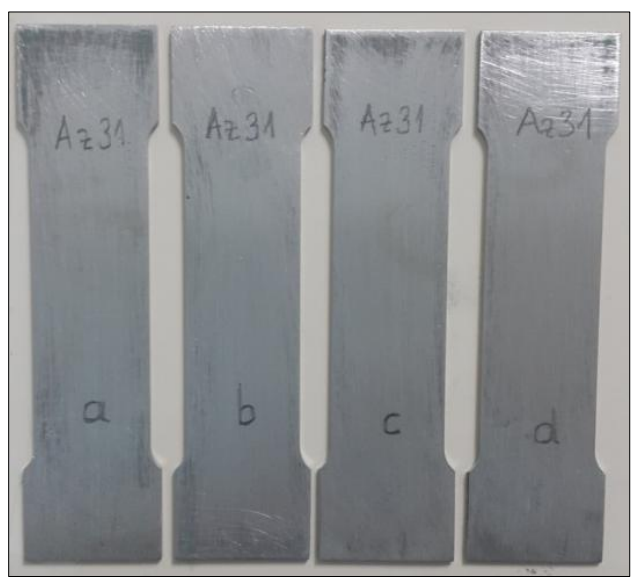

Fig. 2 Tensile test samples of magnesium alloy AZ31B-O according to ISO 6892-1.

Table 1 Chemical composition of magnesium alloy AZ31B [12].

\begin{tabular}{llllllllll}
\hline Alloy & $\mathrm{Al}$ & $\mathrm{Ca}$ & $\mathrm{Cu}$ & $\mathrm{Fe}$ & $\mathrm{Mn}$ & $\mathrm{Ni}$ & $\mathrm{Si}$ & $\mathrm{Zi}$ & $\mathrm{Mg}$ \\
\hline$\%$ & $2.5-3.5$ & 0.04 & 0.05 & 0.005 & $0.2-1.0$ & 0.005 & 0.1 & $0.6-1.4$ & rest \\
\hline
\end{tabular}

Table 2 Mechanical properties of magnesium alloy AZ31B [12].

\begin{tabular}{llll}
\hline Temper. & Tensile strength $(\mathrm{MPa})$ & Yield stress $(\mathrm{MPa})$ & Elongation $(\%)$ \\
\hline $\mathrm{T} 4$ & 240 & 145 & $\geq 7$ \\
\hline
\end{tabular}

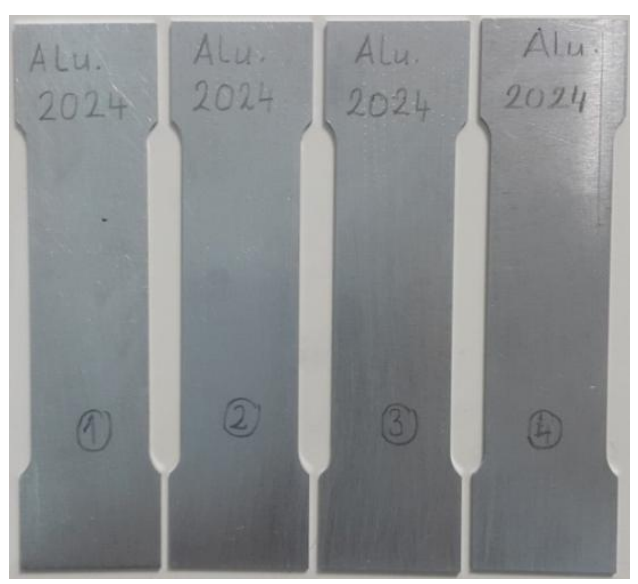

Fig. 3 Tensile test samples of aluminum alloy EN AW 2024-T4 according to ISO 6892-1. 
Table 3 Chemical composition of aluminum alloy EN AW 2024-T4 [13].

\begin{tabular}{llllllllll}
\hline Element & $\mathrm{Al}$ & $\mathrm{Cu}$ & $\mathrm{Mg}$ & $\mathrm{Mn}$ & $\mathrm{Fe}$ & $\mathrm{Cr}$ & $\mathrm{Zi}+\mathrm{Ti}$ & $\mathrm{Zn}$ & $\mathrm{Si}$ \\
\hline$\%$ & $90.7-94.7$ & $3.8-4.9$ & $1.2-1.8$ & $0.3-0.9$ & 0.5 & 0.1 & 0.15 & 0.25 & 0.5 \\
\hline
\end{tabular}

Table 4 Mechanical properties of aluminum alloy EN AW 2024-T4 [13].

\begin{tabular}{lllll}
\hline Temper. & Tensile strength $(\mathrm{MPa})$ & Yield strength $(\mathrm{MPa})$ & Elongation $(\%)$ & Hardness $(\mathrm{HB})$ \\
\hline $\mathrm{T} 4$ & $\geq 275$ & $\geq 12$ & 120 \\
\hline
\end{tabular}

Fig. 4 shows the tension test results. Only two of the four prepared samples (a, b, c, d) gave a reliable results.

Table 5 shows the mechanical properties of $1.5 \mathrm{~mm}$ thick magnesium alloy AZ31B measured by the tension test with a tension speed of $1 \mathrm{~mm} / \mathrm{min}$.

Fig. 5 shows the tension test results for aluminum sheets. All four tests samples $(1,2,3,4)$ gave reliable test results.

Table 6 shows the mechanical properties of the aluminum alloy EN AW 2024-T4 material and the thickness of the $1.2 \mathrm{~mm}$ sheet measured by the tensile test at a speed of $1 \mathrm{~mm} / \mathrm{min}$.

Mechanical properties of magnesium alloy AZ31B and aluminum alloy EN AW 2024-T4 material were determined with the tensile tests. It was concluded that the provided values are in line with values in the standards, which corresponds to the criteria of the standards and therefore the tests are considered as reliable.

\subsection{Tensile-Shear Test}

Standard test samples (AZ31B) welded with shoulder profile type A were exposed to tensile-shear tests. The dimensions for friction stir spot welded samples are showed in Fig. 6. Fig. 7 shows the force-elongation test results for test speed of $10 \mathrm{~mm} / \mathrm{min}$. Average ultimate tensile strength of 4 EN AW 2024-T4 sample materials is $2,820 \mathrm{~N}$ given in Fig. 8 .

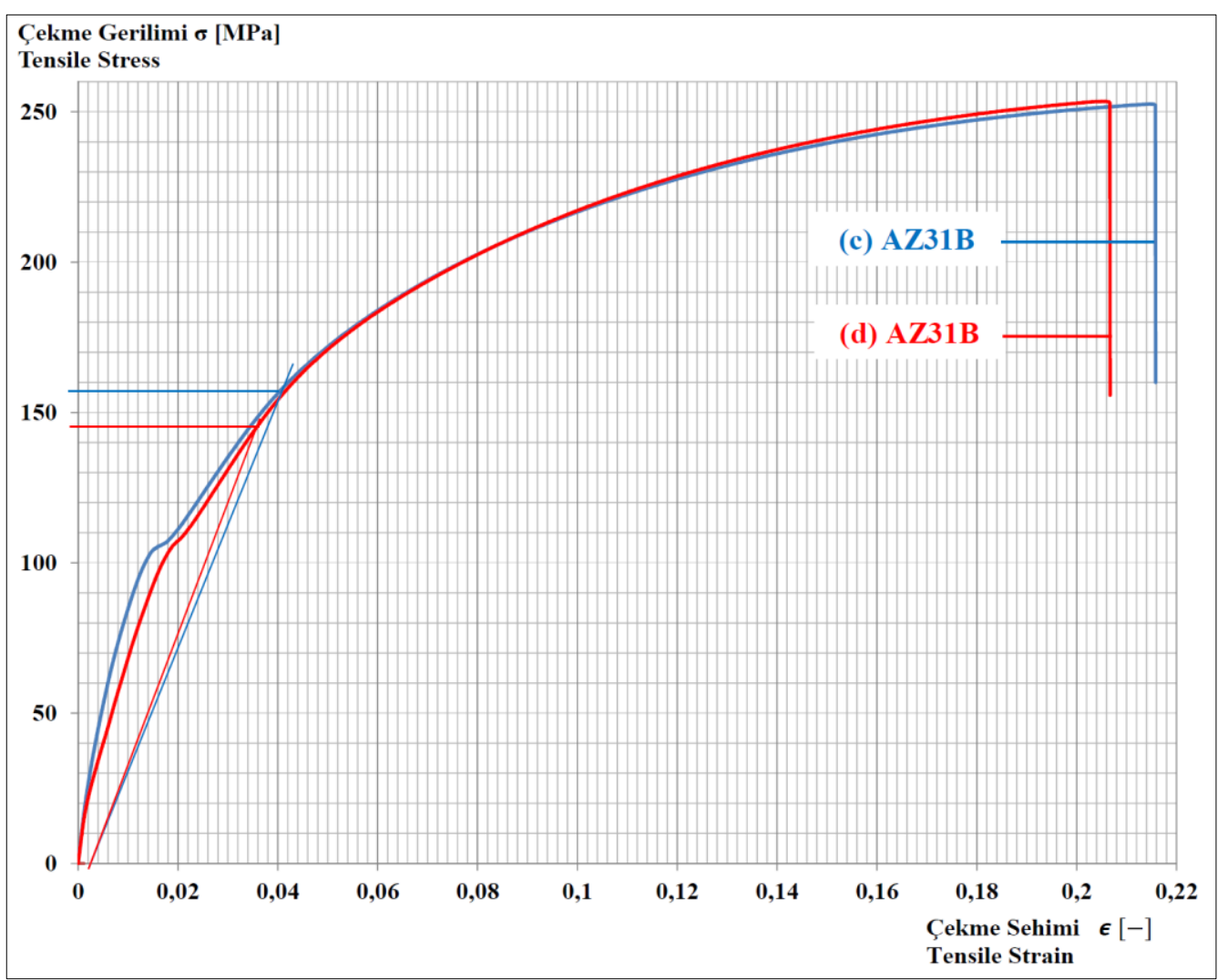

Fig. 4 Tension test results of $1.5 \mathrm{~mm}$ thick magnesium alloy AZ31B with a tension speed of $1 \mathrm{~mm} / \mathrm{min}$. 
Table 5 Mechanical properties of $1.5 \mathrm{~mm}$ thick magnesium alloy AZ31B measured by the tension test with a tension speed of $1 \mathrm{~mm} / \mathrm{min}$.

\begin{tabular}{llll}
\hline Sample/material & Tensile strength $\sigma_{\mathrm{u}}[\mathrm{MPa}]$ & Yield strength $\sigma_{\mathrm{y}}[\mathrm{MPa}]$ & Yield rate A [\%] \\
\hline (c) AZ31B & 252.6 & 156 & 21.8 \\
(d) AZ31B & 253.5 & 146 & 21.0 \\
AZ31B (Avg.) & 253 & 151 & 21.4 \\
\hline
\end{tabular}

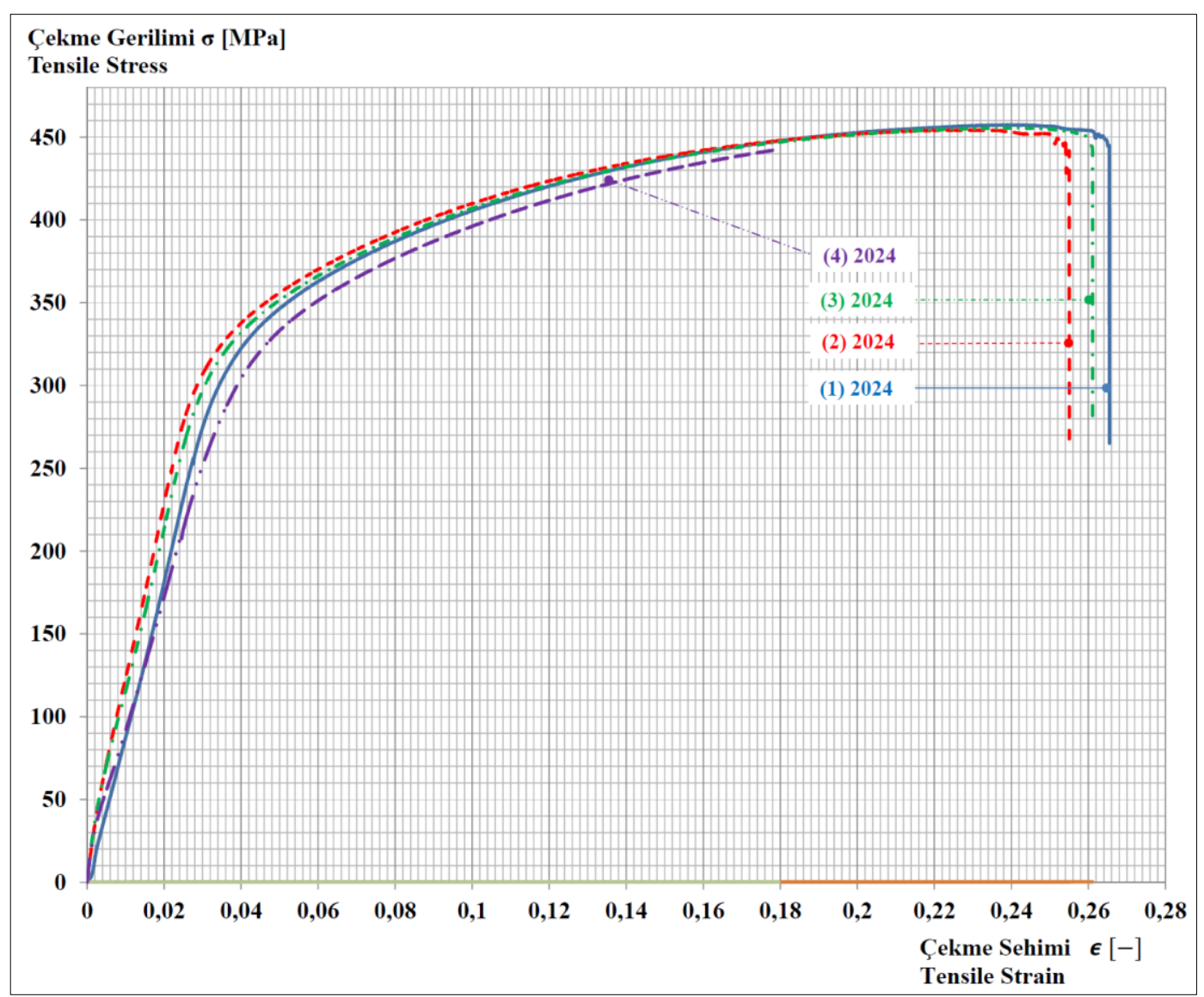

Fig. 5 Tension test results of $1.2 \mathrm{~mm}$ thick aluminum alloy EN AW 2024-T4 with a tension speed of $1 \mathrm{~mm} / \mathrm{min}$.

Table 6 Mechanical properties of $1.2 \mathrm{~mm}$ thick magnesium alloy EN AW 2024-T4 according to tension test with a tension speed of $1 \mathrm{~mm} / \mathrm{min}$.

\begin{tabular}{llll}
\hline Sample/material & Tensile strength $\sigma_{\mathrm{u}}[\mathrm{MPa}]$ & Yield strength $\sigma_{\mathrm{y}}[\mathrm{MPa}]$ & Yield rate A [\%] \\
\hline (1) EN-AW 2024 & 457.5 & 290 & 26.8 \\
(2) EN-AW 2024 & 454.3 & 330 & 25.7 \\
(3) EN-AW 2024 & 455.6 & 325 & 26.5 \\
(4) EN-AW 2024 & 442.6 & 305 & 18.2 \\
EN-AW 2024 (avg.) & 452.5 & 312.5 & 24.3 \\
\hline
\end{tabular}

Table 7 shows the tensile shear test results of different materials such as AZ31B and EN AW 2024-T4 with joining of same shoulder profile (A).

If we compare the average tensile forces obtained in tensile-shear tests to the tensile stress of the material, it can be said that this ratio of EN AW 2024-T4 material is bigger than that in $\mathrm{AZ} 31 \mathrm{~B}$ and therefore the joining of EN AW 2024-T4 is more robust. 


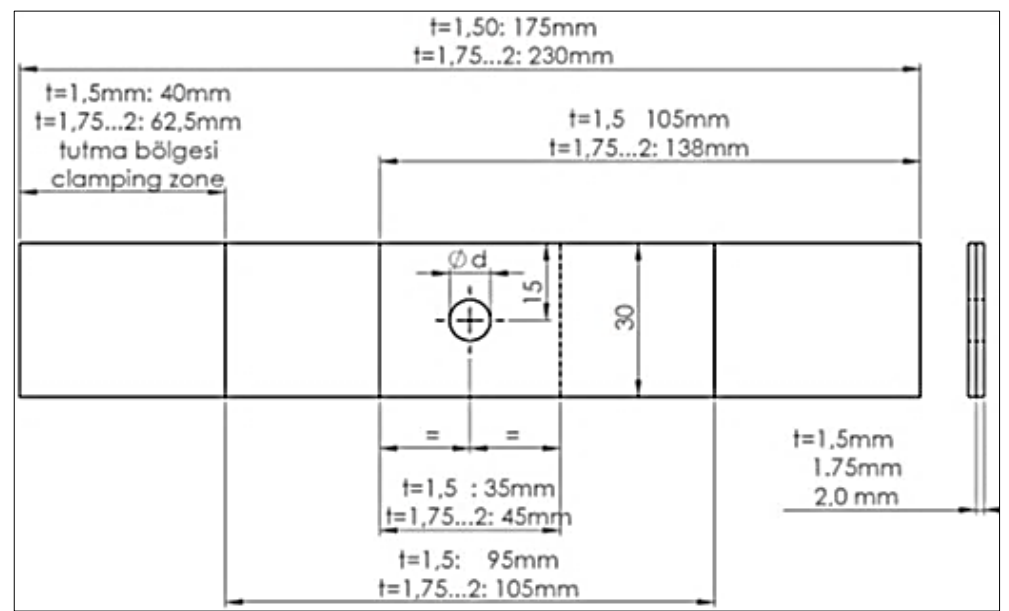

Fig. 6 Joining dimensions for the friction stir spot welding of the test samples.

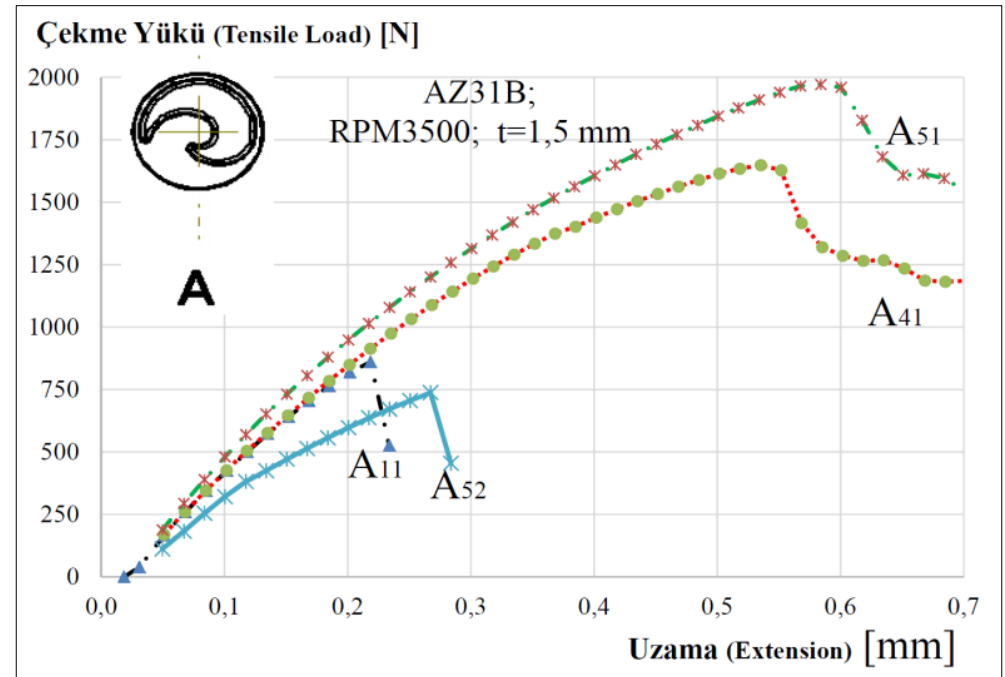

Fig. 7 Force elongation graphic of tensile, shear tests results of $1.5 \mathrm{~mm}$ magnesium alloy AZ31B samples, A11, A41, A51, and $\mathbf{A 5 2}$.

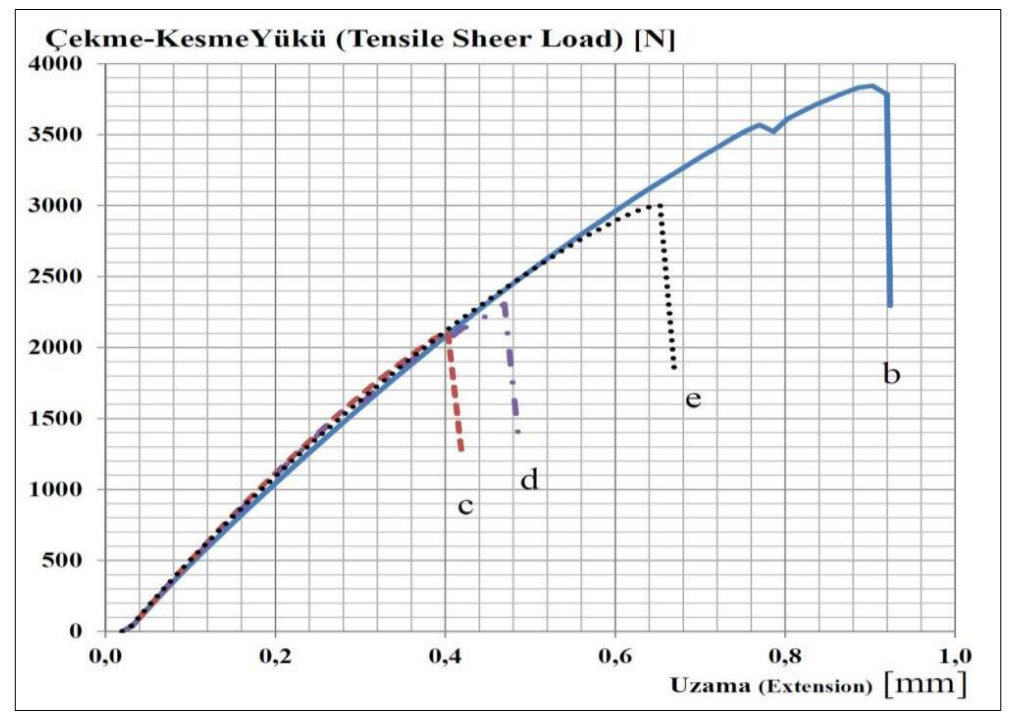

Fig. 8 Force elongation graphic of tensile, shear tests results of $1.2 \mathrm{~mm}$ aluminum alloy EN AW 2024-T4 samples, b, c, $\mathrm{d}$ and e. 
Table 7 Comparison of tensile, shear test results of AZ31B and EN Aw 2024-T4 (Shoulder profile A).

\begin{tabular}{lllll}
\hline Material & Ultimate shear force max. & $\begin{array}{l}\text { Average shear force Fu } \\
{[\mathrm{N}]}\end{array}$ & Tensile strength fu [MPa] & Fu/fu [N/MPa] \\
\hline AZ31B & 1,500 & 1,290 & 240 & 5.4 \\
EN AW 2024-T4 & 3,850 & 2,820 & 425 & 6.6 \\
\hline
\end{tabular}

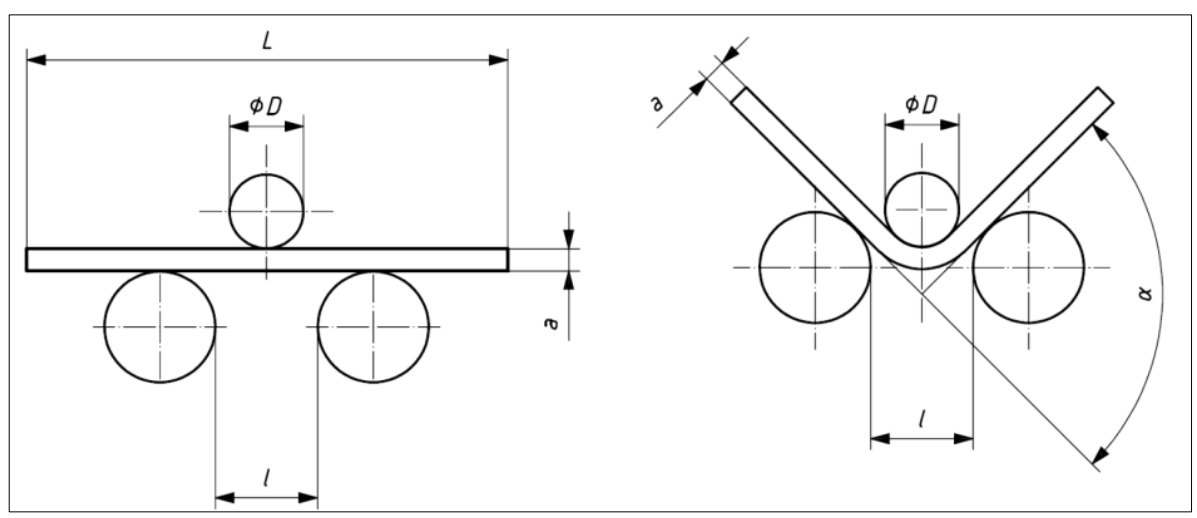

Fig. 9 Set up dimensions for three-point bending tests according to ISO 7038.

\subsection{Three Points Bending Test}

The set-up and its dimensions used for the three-point bending test according to ISO 7038 are shown in Fig. 9. According to this, $a=2 \times 1.5 \mathrm{~mm}=3 \mathrm{~mm} ; D=6$ $\mathrm{mm} ; l=15.5+D+3 a \times a / 2=25 \times 1.5 \mathrm{~mm}$ and the cylinder diameters of the supports were selected as $d=50 \mathrm{~mm}$. An extra $15.5 \mathrm{~mm}$ has been added to the support pitch gauge 1 otherwise the lap area is touched by the support rollers during bending and thus causes incorrect measurement.

Figs. 9 and 10 graphically show the bending force vs. bending deflection values of the three-point bending test after joining of $1.7 \mathrm{~mm}$ and $2.0 \mathrm{~mm}$ magnesium alloy AZ31B sheets with FSW. Joining conditions a re 5-second plunge time and 15 seconds waiting.

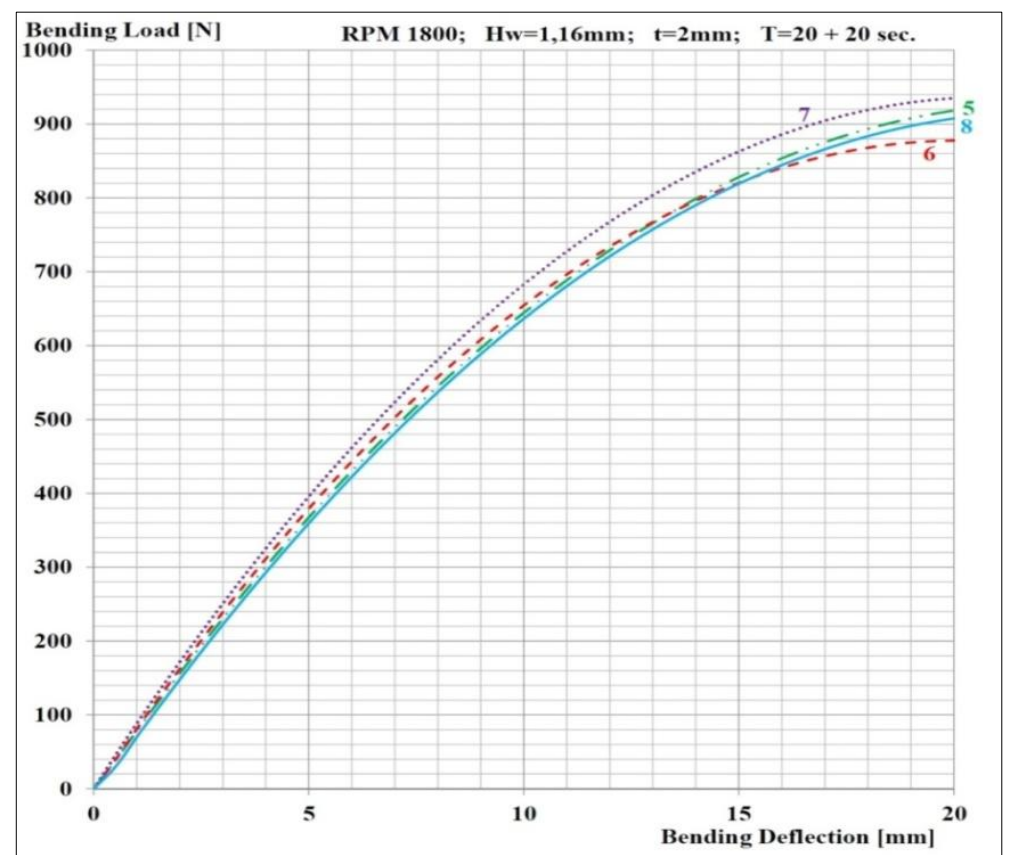

Fig. 10 Graphical representation of bending forces vs. bending deflection according to three-point bending test results of FSW welded $2.0 \mathrm{~mm}$ magnesium alloy AZ31B samples, 5, 6, 7, and 8 . 


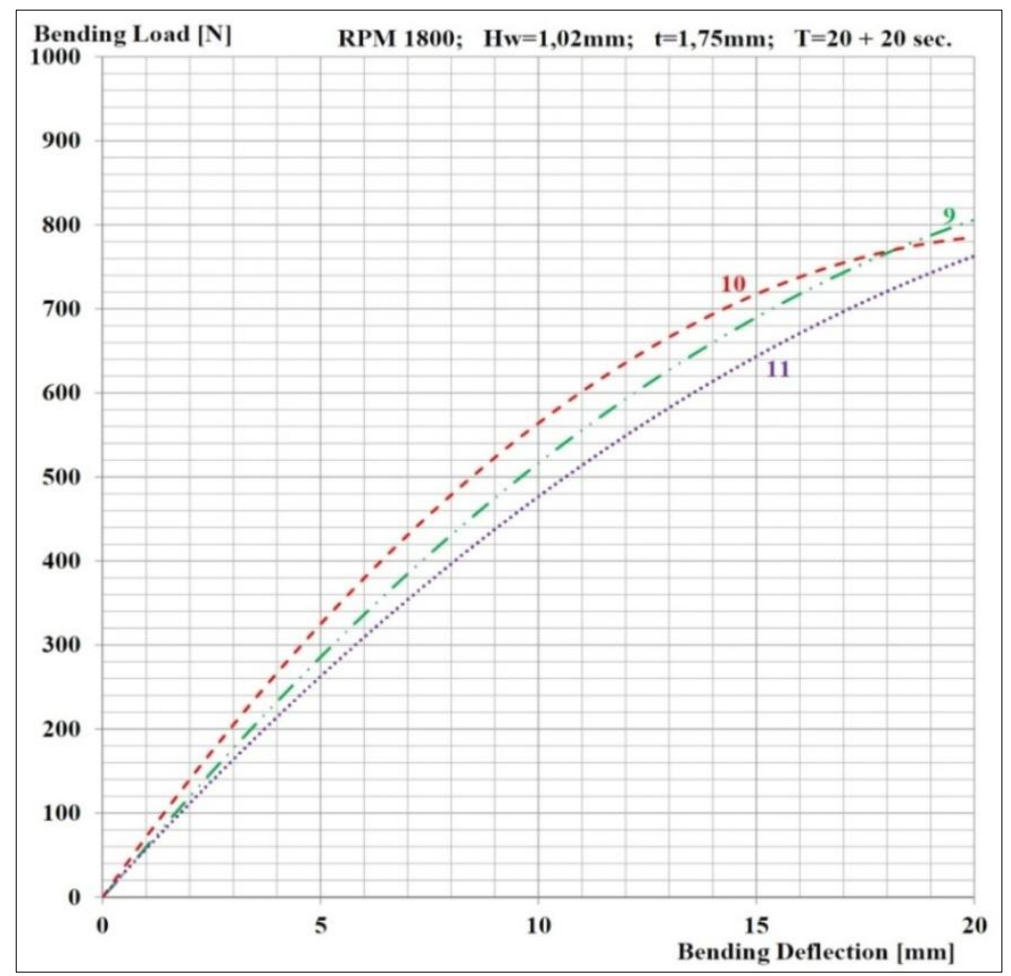

Fig. 11 Graphical representation of bending forces vs. bending deflection according to three-point bending test results of FSW welded $1.75 \mathrm{~mm}$ magnesium alloy AZ31B samples, 9, 10, and 11.

\section{Results and Conclusion}

- It was found that magnesium alloy and aluminum alloy thin plates can be joined together with a friction stir spot welding.

- Base materials used in this study: AZ31B and EN AW 2024, were tested and verified to be in accordance with the specifications given in the standard of mechanical properties.

- If the tensile forces of the base material are compared with the tensile force of the FSW materials, the tensile force in the joined material descends at least the half through the notch factor (about 2.5). This would not be the case if it were a continuous welding instead of a spot welding.

- Higher tensile-shear forces were obtained for aluminum alloy EN AW 2024 material joined with FSW compared to magnesium alloy AZ31B.

- If the three-point bending test results of different thicknesses $(1.75$ and $2.0 \mathrm{~mm}$ ) of magnesium alloy AZ31B sheets compared, almost similar results were obtained.

\section{References}

[1] Kandemir, K., and Can, A. Ç. 2003. "Otomotiv Endüstrisi İçin Magnezyum Alaşımlarının Kullanım Potansiyeli." Pamukkale Üniversitesi Mühendislik Fakültesi Mühendislik Bilimleri Dergisi 1: 37-45.

[2] DTI. 2004. Magnesium Alloys And Processing Technologies For Light weight Transport Applications. Global Watch Mission Report, U.K.

[3] Kaya, A. A., Özdoğru, E. F., Abanoz, D., Yiğit, S., Yücel, O., and Uygulamaları, O. B. A. 2002. "OTEKON02 Otomotiv Teknolojileri Kongresi.” Bursa, 41-6.

[4] Şik, A. 2002. Otomobil saclarının MIG/MAG kaynağında gaz karışımlarının bağlantının mekanik mekanik özelliklerine etkisi, Gazi Üniversitesi Endüstriyel Teknoloji Eğitimi, Doktora tezi.

[5] Atak, A., Şik, A., and Özdemir, V. 2018. "Sürtünme Karıştırma Nokta Kaynağı (SKNK) Yöntemi İle Otomotiv Sektöründe Kullanılan Magnezyum Alaşımlarının Birleştirilmesi.” 9th Interna-tional Automotive Technologies Congres, Otekon 2018, Bursa, Turkey.

[6] Şik, A., and Ayabaş, Ö. 2003. Sürtünme karıştırma kaynağı ile yapılan Alüminyum kaynağında kaynak bölgesinin mekanik özelliklerinin incelenmesi." Gazi Üniversitesi Endüstriyel Sanatlar Eğitim Fakültesi Dergisi 11 (12): 30-43. 
[7] Şik, A. 2010. "Sürtünme Karıştırma Kaynağı İle Birleştirilen Magnezyum Levhaların Mekanik Özelliklerinin İncelenmesi." SAÜ. Fen Bilimleri Dergisi 14 (2): 134-40.

[8] Külekçi, M. K., Şik, A., and Kaluç, E. 2008. "Effects of Tool Rotation and Pin Diameter on Fatigue Properties of Friction Stir Welded Lap Joints." The International Journal of Advanced Manufacturing Technology 36 (9): 877-82.

[9] Gerlich, A., Yamamoto, M., and North, T. H. 2007. "Local Melting and Cracking in Al 7075-T6 and Al 2024-T3 Friction Stir Spot Welds." Science and Technology of Welding and Joining 12 (6): 474-5.

[10] Kaluç, E., and Taban, E. 2007. "Otomotiv Endüstrisinde Direnç Nokta Kaynağına Alternatif Bir Yöntem: Sürtünen Elemanla Nokta Kaynağı (FSSW).” Kaynak
Teknolojisi VI.Ulusal Kongresi ve Sergisi, TMMOB Makine Mühendisleri Odası, 449.

[11] Kaluç, E., and Taban, E. 2007. "Sürtünen Eleman İle Kaynak (FSW) Yöntemi, TMMOB Makine Mühendisleri Odası, TMMOB Makine Mühendisleri Odası, Kaynak Teknolojisi VI. Kongre ve Sergisi Bildiriler Kitabı 460: 60-77.

[12] ASTM B 107/B 107M-07: Standard Specification for Magnesium-Alloy Extruded Bars, Rods, Profiles, Tubes, and Wire, Copyright $\odot$ ASTM International, 100 Barr Harbor Drive, West Conshohocken, PA 19428-2959, United States.

[13] BS EN 485-2:2007: Aluminium and aluminium Alloys-Sheet, Strip and Plate, Part 2: Mechanical properties, British Standard. 